\title{
Evaluation of Spring Wheat Germplasm for Resistance to Bacterial Leaf Streak Caused by Xanthomonas campestris pv. translucens
}

Yuba R. Kandel, Karl D. Glover, and Connie A. Tande, Plant Science Department, South Dakota State University, Brookings 57007; and Lawrence E. Osborne, Pioneer Hi-Bred International, Brookings, SD 57006

\begin{abstract}
Kandel, Y. R., Glover, K. D., Tande, C. A., and Osborne, L. E. 2012. Evaluation of spring wheat germplasm for resistance to bacterial leaf streak caused by Xanthomonas campestris pv. translucens. Plant Dis. 96:1743-1748.

Bacterial leaf streak (caused by Xanthomonas campestris pv. translucens) has reemerged as a potential threat in spring wheat (Triticum aestivum) production areas in the northern Great Plains. As with other foliar bacterial diseases, chemical control under field situations is neither economical nor practical. Development of resistant genotypes will be needed for adequate management of the disease. There is currently limited information on sources of resistance in hard spring wheat germplasm. The main objective was to develop and apply a robust screening tool for evaluating germplasm against bacterial leaf streak, and to identify resistance sources for this disease. Inoculated field experiments were conducted in Brookings and Codington Counties, SD in 2009 and 2010 using a virulent local isolate (XctSD-017) inocu-

lated after tillering stage. Forty-five hard red spring wheat genotypes with diverse genetic backgrounds were evaluated for disease severity, with ratings made at 7-day intervals from heading through dough stage. Results of this study showed clear differences in level of resistance among the 45 genotypes, with no immunity expressed. SD4205 was found resistant to the disease with the lowest area under the disease progress curve across location-years. Other genotypes showing moderate levels of resistance included SD4148, SD4176, 'Alsen', SD4023, 'Faller', SD4024, 'Knudson', and SD4199. Grain weight was negatively correlated to disease, as was days to heading. The resistance identified appeared to be quantitative in nature and was expressed through slower disease progress and reduced severity.
\end{abstract}

Bacterial leaf streak (BLS) of wheat, caused by Xanthomonas campestris pv. translucens (Jones, Johnson, \& Reddy) Dye, has recently emerged as an economically important disease of wheat (Triticum aestivum L.) in parts of the U.S. northern Great Plains. The disease was first reported as early as 1919 (17) in Indiana and by now has been reported to affect several wheat-growing areas in the United States and other countries of the world (4). BLS affects all classes of bread wheat but is generally more damaging to spring wheat under humid conditions. It has been speculated that the major causes of the reemergence of BLS in this region include a low level of resistance in the predominate cultivars, along with changes in environment and cultural practices and, perhaps, evolution of more virulent pathogen populations (9).

Distinct foliar symptoms differentiate BLS from black chaff disease, though both share the same causal agent (X. campestris pv. translucens). The leaf streak form is characterized by yellow or translucent longitudinal stripes extending between the leaf veins along with the production of yellow-orange bacterial exudates (ooze) under humid condition (17). The black chaff form produces striking black streaks or blotches on affected spikes (primarily on glumes) and peduncle tissues (17). The leaf streak form is considered to be the more destructive in terms of yield loss. BLS disease reduces photosynthetic area and causes premature leaf death, resulting in limited grain fill period, lighter test weights, and lower yields (7). Bacteria infect via stomata and multiply in the parenchyma tissue, which causes elongated streaks often limited by veins (4). Rain and wind greatly influence the spread of disease (4)

Corresponding author: L. E. Osborne,

E-mail: larry.osborne@pioneer.com

* The $e$-Xtra logo stands for "electronic extra" and indicates that two supplementary figures are available online.

Accepted for publication 10 June 2012.

http://dx.doi.org/10.1094/PDIS-03-12-0303-RE

(C) 2012 The American Phytopathological Society and are a primary means of its dispersal in fields. Although BLS has at times been considered to be an important disease of wheat, its impact on yield loss has not been well documented in the United States. A study conducted in Mexico reported 20\% yield loss in bread wheat as a linear function of leaf streak severity (7). Studies suggests that yield loss increases as the severity of disease increases due to reduction in seed weight as well as in number of seed per spike (20). Disease severity of $50 \%$ on flag leaves resulted in 8 to $13 \%$ yield loss while $100 \%$ severity on flag leaves resulted in 13 to $34 \%$ yield loss (16). Yield loss estimates in Idaho were shown to reach as high as $40 \%$ (8).

This disease is thought to arise in some cases from contaminated seed $(8,17)$ and, because of this, the disease has become a constraint for international germplasm exchange as well (4). Eradication of the pathogen from the seed may help in controlling the disease but the methods developed thus far to reduce seed infection have not been very effective for controlling the disease at the field level (4). Chemical management of the disease through the use of bactericidal products is not recommended because of the persistent nature of the pathogen and the prolonged window of host susceptibility. It's likely that the only practical, economical, and durable management of the disease would be through the development of resistant genotypes. There are few published studies which identify known sources of resistance to BLS and/or genes conferring resistance to this disease. In studies done two decades ago in Mexico, a few resistant cultivars and five resistance genes useful against BLS were identified (5). 'Pavon 76' and 'Mochis' were identified as highly resistant against BLS in Mexico; however, Pavon 76 was subsequently observed to be severely diseased in Louisiana (19). This underscores the importance of environment-specific studies to identify potential resistance sources. This study was conducted to identify potential sources of resistance against BLS in the northern Great Plains through a rigorous and effective field screening protocol.

\section{Materials and Methods}

Field experiments were carried out in Brookings County (44.18 N 96.40 W) and Codington County (45.11 N 97.10 W), South Dakota, during 2009 and 2010. Forty-five hard red spring wheat geno- 
types, including adapted, released cultivars as well as elite breeding genotypes from the South Dakota State University spring wheat breeding program, were evaluated in this study. The experiment was conducted as a randomized complete block design with three replications. Each plot consisted of a single 1-m row. Planting dates used were typical of the area for each location-year. Previous crops were soybean following spring wheat. Supplemental inoculum was introduced to plots near the tillering stage (Feekes 2 to 3). Inoculum was prepared using a fresh nutrient agar culture of the virulent strain XctSD-17. The isolate used in the study was collected from symptomatic leaf tissues collected from SD fields during the 2008 growing season. It was selected from among a number of virulent isolates based on its growth characteristics and consistent pathogenicity. Field isolates from symptomatic tissues were subjected to pathogenicity testing following Koch's postulates. The isolates were further identified through several physical, physiological, and biochemical methods, including colony morphology, growth on semi-selective XTS agar (14), Gram's stain, oxidase reaction, test for endospores, fluorescence production on King's B media, and pathogenicity on wheat, following protocols outlined by Schaad et al. (15) and Duveiller et al. (4). Isolates were further characterized using the Biolog microplate system (Biolog, Inc.). Bacterial cultures were suspended in phosphate buffer to a concentration of $3 \times 10^{8} \mathrm{CFU} \mathrm{ml}^{-1}$. After adjustment of the concentration, Tween 20 (Sigma-Aldrich) was added to the inoculum suspension to encourage dispersal of the bacterial cells within the suspension. The inoculum suspension was sprayed using a backpack-type sprayer at $138 \mathrm{kPa}$ spray pressure. The bacterial suspension was applied to tillering plants in the field at approximately $86 \mathrm{ml} / \mathrm{m}^{2} 25$ to 26 days after sowing (DAS).

Disease assessment and analysis. Four individual disease scores per plot were recorded at 7- to 9-day intervals starting 60
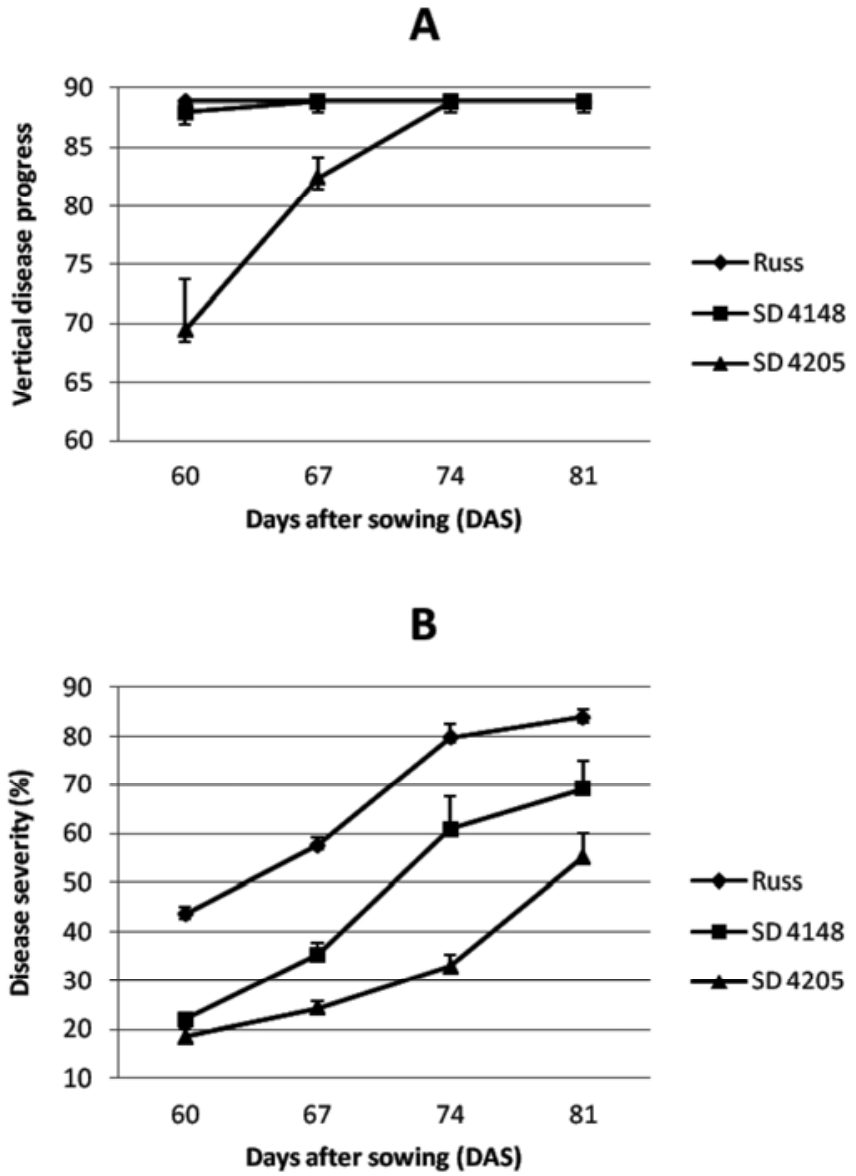

Fig. 1. Vertical disease progress in $\mathbf{A}$, plant canopy and $\mathbf{B}$, disease severity in resistant and susceptible genotypes grown in Brookings and Codington Counties, SD, during 2009 and 2010 wheat seasons. days after sowing, when all genotypes neared the end of heading stage (Feekes 10.5). Disease severity was assessed on each whole plot using a double-digit disease rating scale (range $=00$ to 99 ) developed as a modification of Saari and Prescott's scale (13). This double-digit scale was previously used in assessing Helminthosporium leaf blight severity in wheat (6). The first digit $\left(\mathrm{D}_{1}\right)$ indicates height of disease progress in the plant canopy $(0=$ no disease, $5=$ progress to $50 \%$ of plant height, and $9=$ progress to top of plant). The second digit $\left(\mathrm{D}_{2}\right)$ refers to severity as estimated based on diseased leaf area $(0=$ no disease, $1=10 \%$ leaf area, $2=$ $20 \%$ leaf area, and so on) Both $\mathrm{D}_{1}$ and $\mathrm{D}_{2}$ are scored on a scale of 0 to 9 .

Percent disease severity (PDS) was calculated based on the individual disease score components: percent disease severity $=\left[\left(D_{1} / 9\right)\right.$ $\left.\times\left(D_{2} / 9\right) \times 100\right]$, after Duveiller et al. (6). The percent disease severity was used to calculate area under the disease progress curve (AUDPC) as shown in the equation below:

$$
A U D P C=\sum_{i=1}^{n-1}\left[\frac{D_{(i+1)}+D_{i}}{2}\right]\left[T_{(i+1)}-T_{i}\right]
$$

where $D_{i}=$ disease severity on $i$ th date, $\mathrm{T}_{i}=i$ th date, and $n=$ total number of observations.

At maturity, individual plots were hand harvested and threshed using an Agriculex belt thresher (Model SPT-1; Agriculex, Inc.). A 500-kernel subsample was collected from each plot and weighed to provide an estimate of grain size. Additionally, for the most resistant and most susceptible cultivars, leaf streak length was measured after the final disease rating in 10 randomly selected flag leaves for each genotype.

Statistical analysis. Data were statistically analyzed using the Statistical Analysis System (SAS, version 9.2; SAS Institute Inc.). Analysis of variance was performed for the variables: AUDPC, PDS, vertical disease progress $\left(D_{1}\right)$, and 500 -grain weight. Means separation was done by least significant difference at $P<0.05$. Correlation was calculated among the variable disease severity $\left(D_{2}\right.$, or diseased leaf area) ratings at $\mathrm{T}_{1}, \mathrm{~T}_{2}, \mathrm{~T}_{3}$, and $\mathrm{T}_{4}$; AUDPC; 500grain weights; and days to heading $(\mathrm{DH})$.

\section{Results}

Weather was highly favorable for BLS development in all four location-years. The most susceptible genotypes exhibited approximately $100 \%$ disease on flag leaves, and reisolation from sampled leaf tissue confirmed the presence of the pathogen $X$. campestris pv. translucens. No other significant leaf diseases were evident during the study. No immunity to the disease was observed in any genotype; however, considerable variation in disease severity was observed across genotypes. Disease severity, as measured by AUDPC averaged over all genotypes, was slightly higher in 2010 compared with 2009 and also was generally higher for Brookings County compared with Codington County; however. both locations exhibited high disease levels each year. In general, the relative ranking of genotypes was consistent across location-years and, therefore, location and year variables were removed from a final analysis of variance of genotype response to disease pressure.

There were significant differences in disease height $\left(D_{1}\right.$ scores $)$ among the genotypes at each of the first two observation times (60 DAS, $\mathrm{T}_{1}$; and 67 DAS, $\mathrm{T}_{2}$ ). Subsequent observations at 74 DAS $\left(\mathrm{T}_{3}\right)$ and 81 DAS $\left(\mathrm{T}_{4}\right)$ showed that disease had reached the uppermost leaves for all genotypes (Fig. 1). Disease reached the uppermost leaves earlier in susceptible genotypes compared with SD4205. Although the disease ultimately reached the uppermost leaves on each genotype, the most susceptible genotypes exhibited disease at that height even prior to the first recorded observation $\left(T_{1}\right)$, whereas the more resistant genotypes did not have flag-leaf symptoms until $\mathrm{T}_{3}$ or later. Severity of disease on those leaves was also lower (as reflected by $\mathrm{D}_{2}$ scores) throughout the observation period. The slower disease progress in resistant genotypes was better reflected in AUDPC scores (Table 1) which combined both recorded measures of disease severity $\left(D_{1}\right.$ and $\left.D_{2}\right)$. 
Considerable variability in AUDPC scores was observed among the tested genotypes. AUDPC values averaged over four location-years ranged from 711 for SD4205, the most resistant in the study, to 1,510 for 'Russ', the most susceptible cultivar tested (Table 1). Of the 45 genotypes tested, most would be classified as susceptible or highly susceptible to BLS based on observed symptoms and disease progress scores. The analysis of all four location-years showed a significant genotype-environment (GE) interaction. As alluded to above, the interaction produced only minor differences in the rank order of genotypes relative to disease severity. In other words, genotypes that were highly susceptible at one location-year were also found to be highly susceptible at other location-years. Genotypes with greater resistance at any given location year consistently were among the lowest in AUDPC at other location-years. SD4205 was consistently the most resistant entry, with lowest disease severity across all four environments. SD4148 and SD4176 were considered to be moderately resistant based on observed symptoms and disease development, and had lower average AUDPC values than all other genotypes tested except SD4205. For each of the four loca- tion-years, only nine genotypes were always less than the mean AUDPC for the location-year: SD4205, SD4148, SD4176, 'Alsen', SD4023, 'Faller', SD4024, 'Knudson', and SD4199 exhibited less disease than the test average for each environment. Average AUDPC values for Russ, SD3948, and SD4011, along with observed symptoms, showed these to be highly susceptible genotypes.

Based on the observation that streaks tended to appear longer on more susceptible plants, streak length was measured in the most susceptible (Russ) and most resistant (SD4205) genotypes and it was noted that the average length of the longitudinal translucent streaks in SD4205 (19 mm) was much shorter than that on the susceptible genotype Russ (95 mm)

Analysis of variance for 500-grain weights showed that genotypes varied significantly in kernel weight. Again, as for disease progress data, G-E interaction was statistically significant; however, we were most interested in the effect of disease level on grain weight rather than genotypic or G-E effects. Significant negative correlation was observed between disease severity and both grain weight $(r=-0.51 * *)$ and $\mathrm{DH}\left(0 .-71^{* *}\right)$. Genotypes with less dis-

Table 1. Mean area under the disease progress curve (AUDPC) values for 45 genotypes in a wheat bacterial leaf streak study carried out in Brookings (BRK) and Codington (COD) Counties, SD, during 2009 and 2010 seasons $^{\mathrm{Z}}$

\begin{tabular}{|c|c|c|c|c|c|c|c|}
\hline \multirow[b]{3}{*}{ Genotypes } & \multirow[b]{3}{*}{ Pedigree } & \multirow[b]{3}{*}{ DH } & \multicolumn{4}{|c|}{ AUDPC values } & \multirow[b]{3}{*}{ Mean } \\
\hline & & & \multicolumn{2}{|c|}{2009} & \multicolumn{2}{|c|}{2010} & \\
\hline & & & BRK & COD & BRK & COD & \\
\hline RUSS & SD8052/SD2971 & 54 & 1,477 & 1,422 & 1,587 & 1,552 & $1,510 \mathrm{a}$ \\
\hline SD3948 & SD3367/FN1500-118 & 52 & 1,537 & 1,240 & 1,598 & 1,541 & $1,479 a b$ \\
\hline SD4011 & SD3367/SD3618 & 54 & 1,470 & 1,264 & 1,598 & 1,575 & $1,477 \mathrm{ab}$ \\
\hline SD4187 & SD3618/ND739 & 53 & 1,345 & 1,253 & 1,621 & 1,552 & $1,443 \mathrm{bc}$ \\
\hline SD4171 & BRIGGS/WESLEY//SD3851 & 52 & 1,412 & 1,240 & 1,587 & 1,518 & $1,439 \mathrm{bc}$ \\
\hline SD4076 & SD3546/SD3722 & 52 & 1,450 & 1,220 & 1,575 & 1,506 & $1,438 \mathrm{~b}-\mathrm{d}$ \\
\hline SD4191 & SD3728/MN98389-A & 52 & 1,412 & 1,253 & 1,587 & 1,472 & $1,431 \mathrm{~b}-\mathrm{e}$ \\
\hline SD4158 & MN98389-A/SD3746//GRANITE & 53 & 1,427 & 1,197 & 1,575 & 1,495 & $1,423 \mathrm{~b}-\mathrm{f}$ \\
\hline SD4160 & MN98389-A/SD3746//GRANITE & 53 & 1,394 & 1,264 & 1,587 & 1,372 & $1,404 \mathrm{c}-\mathrm{g}$ \\
\hline SD4036 & N99-0241/SD3641 & 54 & 1,319 & 1,254 & 1,541 & 1,495 & $1,402 \mathrm{c}-\mathrm{g}$ \\
\hline TRAVERSE & SD3305/KS91W005-1-4//SD8089 & 53 & 1,398 & 1,205 & 1,541 & 1,449 & $1,398 \mathrm{c}-\mathrm{h}$ \\
\hline SD4165 & SD3623/ND800//ND747 & 53 & 1,251 & 1,253 & 1,528 & 1,495 & $1,381 \mathrm{~d}-\mathrm{i}$ \\
\hline SD4073 & ND741/SD3623 & 57 & 1,202 & 1,251 & 1,575 & 1,483 & $1,377 \mathrm{e}-\mathrm{j}$ \\
\hline SD4189 & BRIGGS/FHBC02-5 & 54 & 1,383 & 1,193 & 1,481 & 1,449 & $1,374 \mathrm{e}-\mathrm{j}$ \\
\hline SD4035 & N99-0241/SD3641 & 54 & 1,243 & 1,215 & 1,529 & 1,506 & $1,373 \mathrm{f}-\mathrm{k}$ \\
\hline BRICK & ND 2897/SD3219//SD3414 & 51 & 1,284 & 1,083 & 1,564 & 1,483 & $1,354 \mathrm{~g}-1$ \\
\hline BRIGGS & BW114/BERGEN//SD3097 & 52 & 1,330 & 1,156 & 1,458 & 1,460 & $1,351 \mathrm{~g}-1$ \\
\hline OXEN & YW352/SBZ004A & 53 & 1,213 & 1,179 & 1,552 & 1,424 & $1,342 \mathrm{~h}-1$ \\
\hline SD4109 & MN98389-A/FHBC02-9 & 54 & 1,251 & 1,172 & 1,495 & 1,449 & $1,342 \mathrm{~h}-\mathrm{m}$ \\
\hline STEELE-ND & PARSHALL/ND706 & 55 & 1,202 & 1,213 & 1,518 & 1,401 & $1,333 \mathrm{i}-\mathrm{m}$ \\
\hline SD4175 & 2006-27ESWYT-129 & 56 & 1,249 & 1,266 & 1,424 & 1,389 & $1,332 \mathrm{i}-\mathrm{m}$ \\
\hline SD4105 & SD3641/SD3720 & 53 & 1,292 & 1,142 & 1,447 & 1,435 & $1,329 \mathrm{i}-\mathrm{m}$ \\
\hline SD4136 & ND741/SD3714//ND744 & 55 & 1,213 & 1,053 & 1,552 & 1,483 & $1,325 \mathrm{i}-\mathrm{m}$ \\
\hline SD4181 & ND744/SD3540 & 52 & 1,187 & 1,133 & 1,506 & 1,460 & $1,321 \mathrm{j}-\mathrm{m}$ \\
\hline SD4156 & KNUDSON/ND741//N98-0286 & 54 & 1,353 & 1,108 & 1,435 & 1,378 & $1,319 \mathrm{k}-\mathrm{m}$ \\
\hline SD4170 & BRIGGS/WESLEY//SD3851 & 52 & 1,202 & 1,037 & 1,552 & 1,483 & $1,319 \mathrm{k}-\mathrm{m}$ \\
\hline SD4112 & ND749/FHBC02-6 & 53 & 1,236 & 1,098 & 1,495 & 1,437 & $1,3161-n$ \\
\hline SD4046 & PI 584914/SD3730//SD3641 & 54 & 1,236 & 1,179 & 1,424 & 1,412 & $1,3131-0$ \\
\hline GRANGER & SD8070/SD3165 & 54 & 1,330 & 1,133 & 1,445 & 1,342 & $1,3121-0$ \\
\hline KELBY & N97-0117/3/N92-0098//SUMAI3/DALEN & 53 & 1,304 & 927 & 1,529 & 1,449 & $1,3021-\mathrm{o}$ \\
\hline SD4159 & MN98389-A/SD3746//GRANITE & 53 & 1,118 & 1,058 & 1,541 & 1,424 & $1,285 \mathrm{~m}-\mathrm{p}$ \\
\hline SD4119 & PI67392/SD3623//SD3546 & 55 & 1,213 & 1,003 & 1,518 & 1,305 & $1,260 \mathrm{n}-\mathrm{q}$ \\
\hline SD3997 & FN1700-155/FN1500-074//SD3348 & 55 & 1,133 & 1,024 & 1,495 & 1,378 & $1,257 \mathrm{o}-\mathrm{r}$ \\
\hline SD4144 & SD3806/SD3720 & 55 & 1,121 & 984 & 1,411 & 1,449 & $1,241 \mathrm{p}-\mathrm{r}$ \\
\hline SD4178 & SD3720/MN98389-A & 53 & 1,123 & 1,009 & 1,481 & 1,319 & $1,233 \mathrm{p}-\mathrm{s}$ \\
\hline REEDER & IAS20*4/HH567.71//Stoa/3/ND674 & 56 & 1,062 & 1,034 & 1,480 & 1,281 & $1,214 \mathrm{q}-\mathrm{s}$ \\
\hline SD4199 & PI67392/SD3618//ND750 & 53 & 1,019 & 986 & 1,447 & 1,355 & $1,202 \mathrm{r}-\mathrm{t}$ \\
\hline KNUDSON & KARL/KRONA//N90-0669 & 55 & 1,108 & 984 & 1,289 & 1,339 & $1,180 \mathrm{~s}-\mathrm{u}$ \\
\hline SD4024 & SD3546/N99-0230 & 56 & 1,016 & 1,034 & 1,304 & 1,365 & $1,179 \mathrm{~s}-\mathrm{u}$ \\
\hline FALLER & ND2857/3/KITT/AMIDON//GR/STOA SIB & 57 & 1,065 & 1,034 & 1,304 & 1,221 & $1,158 \mathrm{t}-\mathrm{v}$ \\
\hline SD4023 & SD3546/N99-0230 & 56 & 1,045 & 1,022 & 1,267 & 1,278 & $1,153 \mathrm{t}-\mathrm{v}$ \\
\hline ALSEN & ND674//ND2710/ND688 & 56 & 1,012 & 840 & 1,378 & 1,305 & 1,134 uv \\
\hline SD4176 & 2006-27ESWYT-141 & 61 & 968 & 840 & 1,271 & 1,353 & $1,108 \mathrm{wv}$ \\
\hline SD4148 & SD3668/SD3851 & 53 & 797 & 830 & 1,282 & 1,366 & $1,069 \mathrm{w}$ \\
\hline SD4205 & CIMMYT 2003-93 & 62 & 643 & 635 & 757 & 809 & $711 x$ \\
\hline
\end{tabular}

\footnotetext{
${ }^{\mathrm{z}}$ AUDPC for bacterial leaf streak; $\mathrm{DH}=$ days to heading. Means within a column followed by the same letter do not differ significantly based on least
} significant difference at $P=0.05$. 
ease tended to have higher grain weight while those with more disease tended to have lighter grain (Table 2; Fig. 2).

\section{Discussion}

BLS has reemerged and become established as a significant yield-limiting leaf disease in the northern Great Plains over the past 5 to 6 years (9). Precise yield loss models are not available; however, it is clear that the disease poses a major threat to wheat production in this region. Its presence at or around heading time coupled with the potential to severely blight flag leaves makes this disease of utmost concern to the hard red spring and winter wheat producers in the northern Great Plains (2). From a management perspective, as with other bacterial diseases, it is very difficult to manage BLS during the cropping season once it becomes established in the field. The use of resistant cultivars appears to be the most economical and practical means of controlling this disease. Currently, most commercial cultivars used in the region tend to be susceptible or moderately susceptible to BLS. There has been relatively little attention paid to this disease by wheat breeders because it has been only a minor and sporadic pathogen in the region until recently. This study identifies at least one novel source of re- sistance for the disease and describes a strong screening protocol that should be useful for field evaluation of germplasm.

The data and interpretations presented here arise from a field screening protocol incorporating local inoculum (present in the field during the test) as well as supplemental inoculum from a single virulent isolate of the pathogen. In certain pathosystems, it can be useful to challenge host genotypes with a "cocktail" of multiple virulent isolates of the pathogen to avoid mischaracterizing individual lines as "resistant" or "susceptible" due to pathogenic specialization of individual isolates. The virulent isolate XctSD-17 was selected from among a number of isolates that were prescreened for pathogenicity on a small set of wheat lines with putative differential reaction to BLS (including lines that were tested in this study). All isolates that were prescreened produced essentially the same reactions on the differential set, providing evidence that the isolates were similar in their pathogenicity. A single virulent isolate was selected rather than utilizing a cocktail of isolates because the authors had no reason to believe the bacterial population would be sufficiently heterogeneous to warrant multiple-isolate screening.

Assessment of BLS severity at several times over the disease epidemic is required to estimate AUDPC values. Stronger correla-

Table 2. Mean 500-grain weight values for 45 genotypes in a wheat bacterial leaf streak study carried out in Brookings (BRK) and Codington (COD) Counties, SD, during 2009 and 2010 seasons $^{\mathrm{Z}}$

\begin{tabular}{|c|c|c|c|c|c|c|c|}
\hline \multirow[b]{3}{*}{ Genotypes } & \multirow[b]{3}{*}{ Pedigree } & \multirow[b]{3}{*}{ DH } & \multicolumn{4}{|c|}{ 500-grain weights } & \multirow[b]{3}{*}{ Mean } \\
\hline & & & \multicolumn{2}{|c|}{2009} & \multicolumn{2}{|c|}{2010} & \\
\hline & & & BRK & COD & BRK & COD & \\
\hline GRANGER & SD8070/SD3165 & 54 & 13.20 & 16.42 & 14.09 & 15.71 & $14.9 \mathrm{a}$ \\
\hline SD4148 & SD3668/SD3851 & 53 & 14.45 & 15.84 & 13.26 & 13.21 & $14.2 \mathrm{ab}$ \\
\hline SD4205 & CIMMYT 2003-93 & 62 & 16.04 & 15.68 & 11.03 & 12.99 & $14 \mathrm{bc}$ \\
\hline FALLER & ND2857/3/KITT/AMIDON//GR/STOA SIB & 57 & 13.62 & 13.67 & 11.48 & 14.78 & $13.4 \mathrm{~cd}$ \\
\hline SD3997 & FN1700-155/FN1500-074//SD3348 & 55 & 12.66 & 14.18 & 11.56 & 14.25 & $13.2 \mathrm{c}-\mathrm{e}$ \\
\hline KNUDSON & KARL/KRONA//N90-0669 & 55 & 13.76 & 13.52 & 11.63 & 13.61 & $13.1 \mathrm{de}$ \\
\hline SD4187 & SD3618/ND739 & 53 & 14.05 & 13.84 & 11.41 & 13.10 & $13.1 \mathrm{de}$ \\
\hline SD4159 & MN98389-A/SD3746//GRANITE & 53 & 13.43 & 13.78 & 11.17 & 13.18 & $12.9 \mathrm{~d}-\mathrm{f}$ \\
\hline BRIGGS & BW114/BERGEN//SD3097 & 52 & 11.41 & 14.42 & 12.47 & 12.71 & $12.8 \mathrm{~d}-\mathrm{g}$ \\
\hline TRAVERSE & SD3305/KS91W005-1-4//SD8089 & 53 & 11.63 & 14.52 & 11.43 & 13.29 & $12.7 \mathrm{~d}-\mathrm{h}$ \\
\hline SD4199 & PI67392/SD3618//ND750 & 53 & 13.52 & 13.68 & 10.73 & 12.45 & $12.6 \mathrm{~d}-\mathrm{i}$ \\
\hline SD4156 & KNUDSON/ND741//N98-0286 & 54 & 12.25 & 13.11 & 11.12 & 13.85 & $12.6 \mathrm{~d}-\mathrm{i}$ \\
\hline BRICK & ND 2897/SD3219//SD3414 & 51 & 11.98 & 14.54 & 11.04 & 12.68 & $12.6 \mathrm{e}-\mathrm{j}$ \\
\hline SD4112 & ND749/FHBC02-6 & 53 & 12.66 & 13.68 & 11.44 & 12.45 & $12.6 \mathrm{e}-\mathrm{j}$ \\
\hline STEELE-ND & PARSHALL/ND706 & 55 & 13.03 & 12.53 & 11.54 & 12.66 & $12.5 \mathrm{e}-\mathrm{k}$ \\
\hline SD4158 & MN98389-A/SD3746//GRANITE & 53 & 11.54 & 13.76 & 11.10 & 13.26 & $12.4 \mathrm{e}-\mathrm{k}$ \\
\hline RUSS & SD8052/SD2971 & 54 & 12.80 & 12.45 & 11.22 & 12.36 & $12.2 \mathrm{f}-\mathrm{k}$ \\
\hline SD4165 & SD3623/ND800//ND747 & 53 & 13.31 & 13.21 & 10.35 & 11.93 & $12.2 \mathrm{f}-\mathrm{k}$ \\
\hline KELBY & N97-0117/3/N92-0098//SUMAI3/DALEN & 53 & 12.45 & 13.24 & 10.86 & 12.01 & $12.2 \mathrm{f}-1$ \\
\hline SD4178 & SD3720/MN98389-A & 53 & 13.05 & 12.69 & 10.35 & 12.47 & $12.1 \mathrm{f}-1$ \\
\hline SD4170 & BRIGGS/WESLEY//SD3851 & 52 & 12.13 & 13.78 & 10.74 & 11.66 & $12.1 \mathrm{~g}-\mathrm{m}$ \\
\hline SD4136 & ND741/SD3714//ND744 & 55 & 13.25 & 12.73 & 10.08 & 11.71 & $11.9 \mathrm{~h}-\mathrm{n}$ \\
\hline SD3948 & SD3367/FN1500-118 & 52 & 11.51 & 13.34 & 11.06 & 11.82 & $11.9 \mathrm{i}-\mathrm{n}$ \\
\hline SD4023 & SD3546/N99-0230 & 56 & 11.98 & 13.23 & 10.03 & 12.46 & $11.9 \mathrm{~h}-\mathrm{n}$ \\
\hline SD4105 & SD3641/SD3720 & 53 & 11.47 & 12.50 & 13.05 & 10.54 & $11.9 \mathrm{i}-\mathrm{n}$ \\
\hline SD4024 & SD3546/N99-0230 & 56 & 12.14 & 12.73 & 10.75 & 11.90 & $11.9 \mathrm{i}-\mathrm{n}$ \\
\hline SD4160 & MN98389-A/SD3746//GRANITE & 53 & 10.98 & 13.20 & 10.51 & 12.76 & $11.9 \mathrm{i}-\mathrm{n}$ \\
\hline SD4119 & PI67392/SD3623//SD3546 & 55 & 12.32 & 12.94 & 9.92 & 12.25 & $11.9 \mathrm{i}-\mathrm{n}$ \\
\hline SD4144 & SD3806/SD3720 & 55 & 12.21 & 12.60 & 10.82 & 11.78 & $11.9 \mathrm{i}-\mathrm{n}$ \\
\hline ALSEN & ND674//ND2710/ND688 & 56 & 12.54 & 12.29 & 10.34 & 12.16 & $11.8 \mathrm{i}-\mathrm{n}$ \\
\hline SD4011 & SD3367/SD3618 & 54 & 12.18 & 12.98 & 10.44 & 11.72 & $11.8 \mathrm{i}-\mathrm{n}$ \\
\hline SD4035 & N99-0241/SD3641 & 54 & 12.41 & 12.80 & 10.24 & 11.84 & $11.8 \mathrm{i}-\mathrm{n}$ \\
\hline SD4189 & BRIGGS/FHBC02-5 & 54 & 12.10 & 12.10 & 10.13 & 12.74 & $11.8 \mathrm{j}-\mathrm{n}$ \\
\hline SD4181 & ND744/SD3540 & 52 & 12.82 & 11.98 & 10.72 & 11.53 & $11.8 \mathrm{k}-\mathrm{n}$ \\
\hline SD4076 & SD3546/SD3722 & 52 & 11.67 & 12.69 & 10.85 & 11.60 & $11.7 \mathrm{k}-\mathrm{n}$ \\
\hline REEDER & IAS20*4/HH567.71//Stoa/3/ND674 & 56 & 11.86 & 12.14 & 10.37 & 12.37 & $11.7 \mathrm{k}-\mathrm{n}$ \\
\hline SD4109 & MN98389-A/FHBC02-9 & 54 & 11.22 & 12.56 & 10.05 & 11.66 & $11.41-\mathrm{o}$ \\
\hline SD4191 & SD3728/MN98389-A & 52 & 11.47 & 12.10 & 9.79 & 12.11 & $11.41-0$ \\
\hline OXEN & YW352/SBZ004A & 53 & 11.75 & 12.82 & 9.65 & 11.11 & $11.3 \mathrm{~m}-\mathrm{o}$ \\
\hline SD4036 & N99-0241/SD3641 & 54 & 11.55 & 12.46 & 9.93 & 11.31 & $11.3 \mathrm{~m}-\mathrm{o}$ \\
\hline SD4046 & PI 584914/SD3730//SD3641 & 54 & 11.85 & 11.26 & 9.79 & 12.22 & $11.3 \mathrm{~m}-\mathrm{o}$ \\
\hline SD4175 & 2006-27ESWYT-129 & 56 & 11.46 & 10.52 & 10.95 & 12.17 & 11.3 no \\
\hline SD4176 & 2006-27ESWYT-141 & 61 & 12.42 & 11.79 & 8.59 & 10.15 & 10.7 o \\
\hline SD4171 & BRIGGS/WESLEY//SD3851 & 52 & 11.32 & 11.76 & 9.64 & 9.98 & 10.7 o \\
\hline SD4073 & ND741/SD3623 & 57 & 11.43 & 10.19 & 9.13 & 11.65 & 10.6 o \\
\hline
\end{tabular}

${ }^{\mathrm{z}} \mathrm{DH}=$ days to heading. Means within a column followed by the same letter do not differ significantly based on least significant difference at $P=0.05$. 
tion of grain weight with AUDPC than with individual scorings (Table 3) suggests that comparison of cultivars based on the AUDPC value is more reliable for ranking genotypes than one or two individual scorings. In the event that only one scoring is possible, scoring at flowering stage or later is recommended because there is higher correlation $\left(r=0.89^{* *}\right)$ between the later assessment dates with the AUDPC value (Table 3). However, the later assessment dates would likely fail to account for the slower vertical progress of the disease as observed for resistant genotypes in this study. For the most resistant genotypes, it was not until early flowering stage that the disease reached the flag leaves whereas flag leaves were already highly affected in susceptible genotypes. And, although those resistant genotypes had disease on flag leaves after flowering stage, disease was found at a reduced severity as measured by percent leaf area affected compared with more susceptible genotypes.

The differential reaction within the germplasm used in our study agrees with previous studies that showed differential reaction to the disease among different wheat $(2,19)$ and triticale (Triticum $\times \mathrm{Se}$ cale) genotypes (10). In addition, the study identified newer resistant genotypes with moderate to high levels of resistance in current hard red spring wheat germplasm with potential adaptability to the northern Great Plains. In agreement with previous studies, no genotypes showed immunity against the disease $(2,4,5)$. The more-or-less continuous distribution of disease progress scores among the 45 wheat genotypes in this study indicates that resistance against the disease is likely quantitative in nature. This is consistent with the results of several previous studies $(5,11,19)$, which concluded that the resistance against BLS was governed by many genes and quantitatively inherited. Generally, such quantitative resistance is more stable in several host-pathogen systems (18); however, it can be more difficult to identify suitable resistance sources for breeding programs without a robust screening protocol such as that outlined here.

Five genes with additive gene action (B1s1, B1s2, B1s3, B1s4, and Bls5) conferring resistance against the disease were reported from a five-parent diallel crossing scheme in wheat (5). In contrast, resistance to the pathogen in triticale was reportedly governed by a single dominant gene (10). A previous study of black chaff resistance in wheat (21) described resistance conferred by a single dominant gene; however, later it was believed that the study was on inheritance of pseudo-black chaff, a genetic disease-mimic associated with a single gene (5).

Continuously distributed AUDPC value in the tested genotypes made it difficult to group the genotypes into descriptive categories such as "susceptible" or "resistant". When the genotypes were ranked from high to low susceptibility according to AUDPC value, there were clear differences in symptom appearance and progression for genotypes near the top and bottom of the rank order, whereas those genotypes intermediate on the ranking also showed intermediate symptom development and progression. The G-E interaction was significant in this study, supporting a previous report by Tillman et al. (19). This result suggests that environment has a significant effect on expression of BLS in the field. This also indicates the need to conduct screening over multiple environments to avoid errors in characterization due to confounding effects. However, though the $\mathrm{G}-\mathrm{E}$ interactions were significant in this study, the combined analysis across environments was valuable for selecting genotypes with consistently more resistant reactions.

Bacterial streaks in susceptible genotypes are generally more conspicuous than in resistant genotypes (3), which may be due, in part, to greater lesion length, as suggested by measurements reported here. In this study, no clear-cut difference in brightness of the symptom was noticed; however, the difference in streak length was observed among the genotypes. Longer streaks were observed in susceptible genotypes, which suggests that resistant genotypes might have some mechanisms to check the continuous development of the symptom.

The negative relationship between DH and disease severity in this study indicates that DH and BLS resistance might be associated. Effect of relative maturity on expression of BLS resistance was also observed in previous studies $(12,19)$. However, whether the disease resistance and DH are genetically linked is still unclear.

Kernel weight was negatively correlated with the disease severity $\left(r=-0.51^{* *}\right)$. Resistant genotypes had comparatively higher grain weight than the susceptible genotypes (Fig. 2). The reduction

Table 3. Correlations among disease severity and agronomic parameters in a study carried out for bacterial leaf streak in wheat in Brookings and Codington counties, SD, during 2009 and 2010 wheat seasons

\begin{tabular}{lccc}
\hline $\mathbf{D}_{\mathbf{2}}$ time $^{\mathbf{y}}$ & $\mathbf{5 0 0}$-grain weight & AUDPC $^{\mathbf{z}}$ & Days to heading \\
\hline $\mathrm{T}_{1}$ & $-0.20193^{* *}$ & $0.29694^{* *}$ & $\ldots$ \\
$\mathrm{T}_{2}$ & $-0.39742^{* *}$ & $0.74372^{* *}$ & $\ldots$ \\
$\mathrm{T}_{3}$ & $-0.43951^{* *}$ & $0.89728^{* *}$ & $\ldots$ \\
$\mathrm{T}_{4}$ & $-0.45719^{* *}$ & $0.85925^{* *}$ & $\ldots$ \\
AUDPC & $-0.51767^{* *}$ & $\ldots$ & $0 .-71^{* *}$ \\
\hline
\end{tabular}

${ }^{y} D_{2}=$ disease severity ratings taken at $\mathrm{T}_{1}, \mathrm{~T}_{2}, \mathrm{~T}_{3}$, and $\mathrm{T}_{4}=60,67,74$, and 81 days after sowing, respectively.

${ }^{\mathrm{z}}$ Area under disease progress curve.

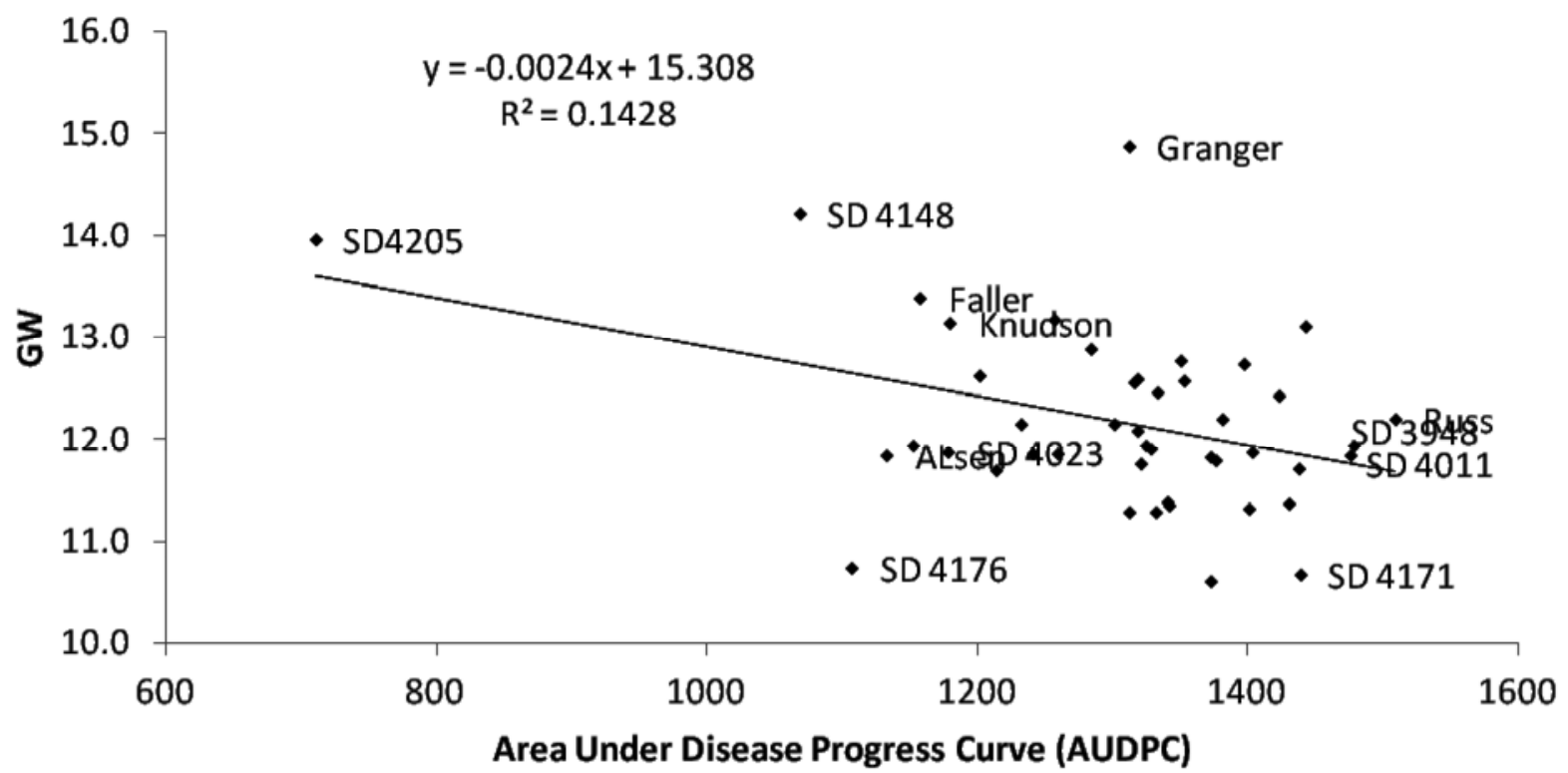

Fig. 2. Scatter diagram of disease severity and 500-grain weight averaged over two locations Brookings and Codington Counties, SD, grown in 2009 and 2010. 
in grain weight might be the result of shriveled grain resulting from reduced photosynthetic area during the grain filling period and, subsequently, lower carbohydrate production in leaves resulting in reduced starch accumulation in grain, which was in agreement with the previous results $(1,16)$. However, the yield component also depends on other factors not measured in this study; therefore, a detailed yield-loss study is recommended.

The findings presented here provide useful methods for screening germplasm and identifying sources of BLS resistance. It will be important to continue to introgress resistant traits into adapted germplasm in order to provide the necessary management tools to the wheat industry in the region. Furthermore, the information provides additional insight into the etiology of the disease on hard red spring wheat that will be useful to epidemiologists and in development of integrated disease management strategies. The pathogen identification technique, inoculation technique, and disease rating scale applied in this study should be useful in future studies in this type of pathosystem.

\section{Acknowledgments}

This work was supported by the South Dakota Wheat Commission and Minnesota Wheat Research and Promotion Council. We thank J. Kleinjan, D. Karki, M. Kadariya, and J. Acharya for their assistance in carrying out the experiment.

\section{Literature Cited}

1. Duveiller, E. 1989. Research on 'Xanthomonas translucens' of wheat and triticale at CIMMYT. EPPO Bull. 19:97-103.

2. Duveiller, E. 1990. Screening criteria for bacterial leaf streak in bread wheat, durum wheat, and triticale. Pages 1011-1016 in: Proc. 7th Int. Conf. Plant Pathogenic Bacteria. Z. Klement et al. eds. Akademiai Kiado, Budapest.

3. Duveiller, E. 1994. A pictorial series of disease assessment keys for bacterial leaf streak of cereals. Plant Dis. 78:137-141.

4. Duveiller, E., Fucikovsky, L., and Rudolph, K., eds. 1997. The Bacterial Diseases of Wheat: Concepts and Methods of Disease Management. CIMMYT, Mexico, D.F.

5. Duveiller, E., Ginkel, M., and Thijssen, M. 1993. Genetic analysis of resistance to bacterial leaf streak caused by Xanthomonas campestris pv. undulosa in bread wheat. Euphytica 66:35-43.

6. Duveiller, E., Kandel, Y. R., Sharma, R. C., and Shrestha, S. M. 2005.
Epidemiology of foliar blights (spot blotch and tan spot) of wheat in the pains bordering the Himalayas. Phytopathology 95:248-256.

7. Duveiller, E., and Maraite, H. 1993. Study of yield loss due to Xanthomonas campestris pv. undulosa in wheat under high rainfall temperate conditions. J. Plant Dis. Prot. 100:453-459.

8. Forster, R. L., and Schaad, N. W. 1988. Control of black chaff of wheat with seed treatment and a foundation seed health program. Plant Dis. 72:935938.

9. Ishimaru, C. A., Samac, D., and Dill-Macky, R. 2010. Bacterial leaf stripe of wheat: an emergent problem in need of solutions. In: Prairie Grains, Minnesota Association of Wheat Growers, North Dakota Grain Growers Association, Montana Grain Growers Association, and South Dakota Wheat, Inc.

10. Johnson, J. W., Cunfer, B. M., and Morey, D. D. 1987. Inheritance of resistance to Xanthomonas campestris pv. translucens in triticale. Euphytica 36:603-607.

11. Milus, E. A., and Chalkley, D. B. 1994. Virulence of Xanthomonas campestris pv. translucens on selected wheat genotypes. Plant Dis. 78:612-615.

12. Milus, E. A., Duveiller, E., Kirkpatrick, T. L., and Chalkey, D. B. 1996 Relationships between disease reactions under controlled conditions and severity of wheat bacterial streak in the field. Plant Dis. 80:726-730.

13. Saari, E. E., and Prescott, J. M. 1975. A scale for appraising the foliar intensity of wheat diseases. Plant Dis. Rep. 59:377-380.

14. Schaad, N. W., and Froster, R. L. 1985. A semiselective agar medium for isolating Xanthomonas campestris pv. translucens from wheat seeds. Phytopathology 75:260-263.

15. Schaad, N. W., Jones, J. B., and Chun, W., eds. 2001. Laboratory Guide for Identification of Plant Pathogenic Bacteria, Third ed. American Phytopathological Society, St. Paul, MN.

16. Shane, W. W., Baumer, J. S., and Teng, P. S. 1987. Crop losses caused by Xanthomonas streak on spring wheat and barley. Plant Dis. 71:927-930.

17. Smith, E. F., Jones, L. R., and Reddy, C. S. 1919. The black chaff of wheat. Science 50:48.

18. St. Clair, D. A. 2010. Quantitative disease resistance and quantitative resistance loci in breeding. Annu. Rev. Phytopathol. 48:247-268.

19. Tillman, B. L., Harrison, S. A., Clark, C. A., Milus, E. A., and Russin, J. S 1996. Evaluation of bread wheat germplasm for resistance to bacterial streak. Crop Sci. 36:1063-1068.

20. Tillman, B. L., Kursell, W. S., Harrison, S. A., and Russin, J. S. 1999. Yield loss caused by bacterial streak in winter wheat. Plant Dis. 83:609-614.

21. Woo, S.-C., and Smith, G. S. 1962. A genetic study of leaf sheath barbs, auricle hairs, and reaction to stem rust and "black chaff" in crosses of $($ ND105 $\times$ ND1) and ND113 with Conley wheat. Bot. Bull. Acad. Sin. 3:195-203. 